\title{
Treatment of an Alveolar Rhabdomyosarcoma Allograft with Recombinant Myxoma Virus and Oclacitinib
}

This article was published in the following Dove Press journal: Oncolytic Virotherapy

\author{
Laura $\vee$ Ashton (iD) \\ Barbara Graham (iD) \\ Maryam F Afzali \\ Daniel Gustafson ${ }^{2}$ \\ Amy L MacNeill (iD) \\ 'Department of Microbiology, \\ Immunology, and Pathology, College of \\ Veterinary Medicine and Biomedical \\ Sciences, Colorado State University, Fort \\ Collins, CO, USA; ${ }^{2}$ Departiment of \\ Clinical Sciences, College of Veterinary \\ Medicine and Biomedical Sciences, \\ Colorado State University, Fort Collins, \\ CO, USA
}

Purpose: Rhabdomyosarcomas (RMS) are difficult tumors to treat with conventional therapies. Publications indicate that oncolytic virotherapy (OV) could benefit cancer patients with tumors that are refractory to conventional treatments. It is believed that the efficacy of OV can be enhanced when used in combination with other treatments. This study evaluated the response of mice with aggressive alveolar RMS (ARMS) allografts to treatment with an OV [recombinant myxoma virus (MYXV $\Delta$ serp2)] in combination with a Janus kinase (JAK) inhibitor (oclacitinib). Oclacitinib is known to inhibit JAK1 and JAK2 cell signaling pathways, which should limit the antiviral Type I interferon response. However, oclacitinib does not inhibit immune pathways that promote antigen presentation, which help stimulate an anti-cancer immune response.

Materials and Methods: To determine if MYXV $\Delta$ serp2 and oclacitinib could improve outcomes in animals with ARMS, nude mice were inoculated subcutaneously with murine ARMS cells to establish tumors. Immune responses, tumor growth, and clinical signs in mice treated with combination therapy were compared to mice given placebo therapy and mice treated with OV alone.

Results: Combination therapy was safe; no viral DNA was detected in off-target organs, only within tumors. As predicted, viral DNA was detected in tumors of mice given oclacitinib and MYXV $\Delta$ serp2 for a longer time period than mice treated with $\mathrm{OV}$ alone. Although tumor growth rates and median survival times were not significantly different between groups, clinical signs were less severe in mice treated with OV.

Conclusion: Our data indicate that MYXV $\Delta$ serp2 treatment benefits mice with ARMS by reducing clinical signs of disease and improving quality of life.

Keywords: oncolytic virus, poxvirus, Janus kinase inhibitor, sarcoma

\section{Introduction}

Soft tissue sarcomas (STS) are a group of neoplasms that are locally invasive, difficult to completely excise surgically, and have variable response rates to adjunctive treatment with radiation and chemotherapy. Over half of the STS in people under the age of 20 are classified as rhabdomyosarcomas (RMS). ${ }^{1}$ RMS originate from pluripotent mesenchymal cells within skeletal muscle. ${ }^{2}$ The annual incidence of RMS is 4.5 cases per million people under 20 years of age, making RMS one of the most common tumors in children. ${ }^{3}$ There are two main subtypes of RMS, embryonic RMS and alveolar RMS (ARMS), which have histological and genetic differences. ${ }^{4}$ The 5 -year survival rates for children with embryonic RMS and ARMS are approximately $73 \%$ 
and $48 \%$, respectively. ${ }^{3}$ Given the high rate of disease recurrence, there is a demand for strategies to improve survival rates of patients with RMS without compromising quality of life. Recent advances in the field of oncolytic viral (OV) therapeutics have showcased the potential effectiveness and safety of this treatment modality. For example, an oncolytic herpes virus was recently approved for use in the United States to treat melanoma. ${ }^{5}$ Studies using attenuated herpes simplex virus and poxvirus therapies have demonstrated oncolytic effects of OVs in sarcoma cells lines and sarcoma xenograft models. ${ }^{6-8}$ Oncolytic virotherapy has fewer side effects than radiation or chemotherapy and may prove to be more effective at reducing recurrence of RMS.

Myxoma virus (MYXV) is an OV that replicates in cultured cancer cells from several animal species, ${ }^{9-12}$ but does not cause disease in humans or other vertebrates (with the exception of rabbits). ${ }^{13-18}$ MYXV is a leporipoxvirus and, like other poxviruses, it does not require a specific cellular receptor to infect cells. When poxviruses enter cells, gene transcription begins immediately and all replication steps occur in the cytoplasm. Mature poxviruses virions are released from infected cells before cell lysis occurs. ${ }^{19}$ These virions effectively enter neighboring cells, spreading the virus infection in susceptible cells throughout the tumor microenvironment. ${ }^{19}$ Importantly, poxviruses elicit strong cell-mediated and humoral immune responses that clear the virus from the body and prevent latent or recurrent infections from occurring. ${ }^{20,21}$

The efficacy of MYXV treatment has been demonstrated in several murine cancer xenograft and allograft models, but complete cures are rarely achieved with OV therapy alone. ${ }^{6,22-27}$ This may be due, in part, to limited viral replication within treated tumors. In mice, MYXV replicates within a tumor for approximately 4 days after virus injection. ${ }^{23}$ When MYXV is injected repeatedly, outcome is improved. ${ }^{6}$ The ability of MYXV to replicate in cancer cells has been shown to be due in part to a lack of interferon (IFN) response in those cells. ${ }^{11,28}$ In an attempt to improve the efficacy of MYXV oncolytic therapy, we used a recombinant MYXV with deletion of a viral anti-apoptotic protein, serp2 (MYXVAserp2). Deletion of serp2 from MYXV markedly attenuates pathogenesis in rabbits ${ }^{29}$ and enhances the oncolytic effects cancer cells. ${ }^{9,10}$ Additionally, we evaluated if MYXV $\Delta$ serp2 oncolytic effects could be improved, without the need of multiple injections, by strategically managing the antiviral IFN immune response in the tumor microenvironment by administering oclacitinib in combination with $\mathrm{OV}$ therapy.
Oclacitinib (Zoetis, Apoquel, Parsippany-Troy Hills, NJ, USA) is a Janus kinase (JAK) inhibitor that has shown safety and efficacy in the treatment of canine allergic disease without inhibiting response to vaccination. ${ }^{30}$ It effectively inhibits JAK1 and JAK2 activation, but has relatively weak activity against JAK3 and tyrosine kinase 2 (Tyk2). ${ }^{31}$ Interleukin-6 (IL-6) and IL-13 (which signal through JAK $1 / 2$ and Tyk2) are inhibited by oclacitinib therapy in dogs. ${ }^{31}$ Oclacitinib also is predicted to inhibit Type I IFN signaling which occurs through JAK1 and Tyk2 pathways. Cytokines of the innate immune response that do not signal through JAK1 [including IL-12, IL-23 and granulocytemonocyte colony-stimulating factor (GM-CSF)] are not inhibited during oclacitinib administration. ${ }^{31}$ We theorized that short-term inhibition of Type I IFN signaling by oclacitinib could allow viral replication to occur in the tumor for a longer period of time, enhancing oncolysis, while cytokines involved in innate immune system continued to stimulate the antitumoral immune response.

\section{Materials and Methods Cells}

Murine ARMS (U21089) cells were a generous gift from Dr. Charles Keller whose laboratory had established the primary cell culture from rhabdomyosarcomas that arose in conditional knockout mice with activation of an oncogene (Pax3:Fkhr) and mutation of a tumor suppressor gene. ${ }^{32}$ Rabbit-kidney epithelial (RK-13) cells were obtained from the American Type Culture Collection (ATCC CCL-37). Cell growth media was comprised of Minimal Essential Medium with Earle's salts and $2 \mathrm{mM}$ L-glutamine supplemented with $2 \mathrm{mM} \mathrm{L}$-glutamine, $50 \mathrm{U} /$ $\mathrm{mL}$ penicillin, and $50 \mu \mathrm{g} / \mathrm{mL}$ streptomycin (Hyclone, Logan, UT, USA); $0.1 \mathrm{mM}$ nonessential amino acids and $1 \mathrm{mM}$ sodium pyruvate (Corning, Corning, NY, USA); and $10 \%$ fetal bovine serum (FBS; VWR Life Science Seradigm, Radnor, PA, USA). Cells were maintained in a water-jacketed incubator at $5 \% \mathrm{CO}_{2}$ and $37^{\circ} \mathrm{C}$.

\section{Viruses}

Wild-type MYXV (Lausanne strain) was originally acquired from Dr. Grant McFadden. Construction and characterization of recombinant MYXV expressing tandem dimer tomato red, ${ }^{33}$ and MYXV $\Delta$ serp $2^{34}$ have been previously described. MYXV $\Delta$ serp2 was amplified in RK-13 cells, sucrose padpurified, and re-suspended in sterile phosphate buffered saline (PBS) prior to injection into mice bearing ARMS. Virus 
titers [plaque/foci-forming units (pfu)/mL] of MYXV and MYXV $\Delta$ serp2 were determined by incubating RK-13 cells with virus inoculum for 30 minutes $5 \% \mathrm{CO}_{2}$ and $37^{\circ} \mathrm{C}$ then adding a solid overlay of 1-part $2 \times$ growth media and incubating for 4 days at $5 \% \mathrm{CO}_{2}$ and $37^{\circ} \mathrm{C}$. Virus titers, the number of viral foci that formed in $\mathrm{RK}-13$ cells per $\mathrm{mL}$ of virus added, were calculated to determine $\mathrm{pfu} / \mathrm{mL}$ of virus.

\section{Growth Rate of MYXV in U21089 Cells}

The growth rate of MYXV and MYXV $\Delta$ serp2 in U21089 cells was evaluated as follows. Growth media (detailed above) was removed from wells of U21089 cells when they were $80 \%$ confluent $\left(1.8 \times 10^{6}\right.$ cells/well $)$. Cells were inoculated with MYXV or MYXV $\Delta$ serp2 at a multiplicity of infection (moi) of $0.01 \mathrm{pfu} /$ cell in media lacking FBS. Cells were incubated with virus for $1 \mathrm{~h}$ at $5 \% \mathrm{CO}_{2}$ and $37^{\circ} \mathrm{C}$. Viral inoculum was removed, cells were rinsed with PBS, and growth media was added to wells. Cells were scraped into growth media at designated time-points post-inoculation, centrifuged at $400 \times \mathrm{g}$ for $15 \mathrm{~min}$, washed in PBS, re-suspended in media lacking FBS, frozen and thawed 3 times, and sonicated. Viral lysates were serially diluted in media lacking FBS and incubated on RK-13 cells for $30 \mathrm{~min}$. A solid overlay of 1-part $2 \times$ growth media and 1 part $1 \%$ agarose was placed on the infected cells. Viral foci were counted 4 days later. Pfu/per U21089 cell was calculated and plotted versus time.

\section{Cytolysis by MYXV in U21089 Cells}

Confluent U21089 cells were incubated with MYXV or MYXV $\Delta \operatorname{serp} 2(\operatorname{moi}=1)$ or mock-infected with media without FBS as described above. Cytopathic effects of virus inoculation, including clustering of cells, disruption of nuclear shape and size, and release of cells from the monolayer into the media, were observed microscopically at 24, 48, and $72 \mathrm{~h}$ post-inoculation (hpi). Cell-titer blue reagent (Promega, Madison, WI, USA) was added to the cell culture media to detect viable cells at 24,48 , and 72 hpi. A Synergy H1 microplate reader (BioTek, Winooski,
VT, USA) was used to detect differences in the amount of cell-titer blue reagent that was metabolized by the cells (fluorescence excitation $=560 \mathrm{~nm}$; emission $=590 \mathrm{~nm}$ ).

\section{Mouse Studies}

All mouse studies were approved by the Institutional Animal Care and Use Committee at Colorado State University (protocol \#17-7709A). American Association for Laboratory Animal Science guidelines were used for the treatment and housing of the mice. Veterinary Medical Association guidelines for humane euthanasia were followed. Murine ARMS allografts were established in sixto eleven-week-old, B6.Cg-Foxn1nu/J mice by injecting 3 $\times 10^{6}$ U21089 ARMS cells subcutaneously (SQ) in the lateral aspect of the thigh. Seven days after tumor cells were injected, either placebo $(30 \mu \mathrm{L} 0.5 \%$ methylcellulose $/ 0.25 \%$ Tween 20 solution) or $45 \mathrm{mg} / \mathrm{kg}$ oclacitinib diluted in $30 \mu \mathrm{L}$ $0.5 \%$ methylcellulose $/ 0.25 \%$ Tween 20 solution was administered orally (PO) twice daily for 14 days. The oclacitinib dose was chosen based upon its published clinical effectiveness in mice. ${ }^{35,36}$ Intratumoral (IT) injection of PBS or $10^{6}$ pfu of sucrose-purified MYXV $\Delta$ serp2 in $100 \mu \mathrm{L}$ PBS was administered 16 days after tumor cells were injected. A second dose of PBS or MYXV $\Delta$ serp2 was injected IT two weeks after the first dose, if the mouse survived to that time point. A timeline for injections and oral treatments is diagramed in Figure 1. In total, 36 mice were given placebo PO and PBS IT (PBS), 36 mice were given placebo PO and

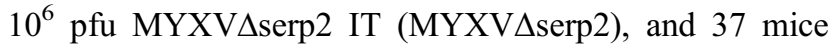
were given oclacitinib PO and $10^{6} \mathrm{pfu}$ MYXV $\Delta$ serp2 IT $(\mathrm{O}+\mathrm{MYXV} \Delta \mathrm{serp} 2)$. Twelve mice in each treatment group were humanely euthanized and necropsied on Days 4 and 7. Twelve mice in the PBS and MYXV $\Delta$ serp2 treatment groups and 13 mice in the $\mathrm{O}+\mathrm{MYXV} \Delta \operatorname{serp} 2$ treatment group were euthanized when a criterion for euthanasia was reached. Criteria for euthanasia included tumor volume $\geq$ $3500 \mathrm{~mm}^{3}$, ulceration of tumors, lethargy or signs of pain,

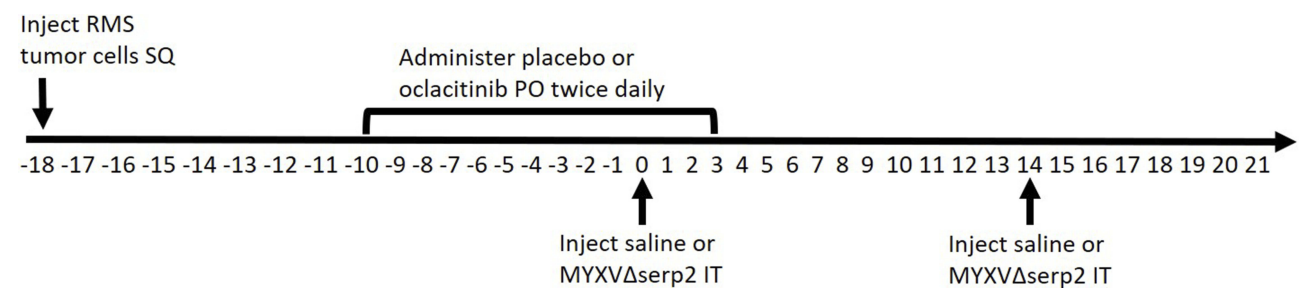

Figure I Diagram of the timeline (in days) of oral (PO) and intratumoral (IT) treatments given to mice bearing subcutaneous (SQ) rhabdomyosarcomas (RMS). Day 0 was designated as the first day that IT treatment was administered. Subsets of mice were euthanized on Days 4 and 7 for sample collection. The shortest and longest survival times were Day II and Day 3I, respectively. 
or loss of $>25 \%$ of the maximum body weight of the mouse.

\section{Assessment of Clinical Condition}

Individual mice were monitored daily for weight, tumor diameter, and clinical appearance. The number of mice in each treatment group with limb swelling, hematoma formation, erythema, ecchymosis, ulceration, and/or impaired mobility was tallied on Days 0, 4, 7, and 14. Contingency data of affected and unaffected animals in each treatment group at each time-point were compiled and analyzed.

\section{Analysis of Viral Spread and Organ Pathology}

All major internal organs and the tumor site were examined and collected during necropsy for assessment of gross appearance, isolation of viral DNA using droplet digital PCR (ddPCR; BioRad, Hercules, CA, USA), and histopathology. For PCR, frozen tissues were weighed then placed into $1.5 \mathrm{~mL}$ sterilized tubes containing $2.0 \mathrm{~mm}$ zirconia beads. $250 \mu \mathrm{L}$ PBS was added to each sample. Samples were homogenized for $5 \mathrm{~min}$ using a MiniBeadbeater (BioSpec, Atkinson, NH, USA). DNA was extracted from homogenized tissue sections using the QIAGEN DNeasy blood and tissue kit (Qiagen NV,
Venlo, Netherlands) according to the manufacturer's instructions. Purity and concentration were measured using 260nm/280nm ratios on a BioTek Take3 MicroVolume Plate and the BioTek Synergy H1 Multi-Mode Reader. Approximately $100 \mathrm{ng}$ of DNA was combined with QX200" ${ }^{\mathrm{TM}}$ ddPCR ${ }^{\mathrm{TM}}$ EvaGreen Supermix (BioRad, Hercules, CA, USA) to perform ddPCR. Primer sets used for detection of MYXVAserp2 by ddPCR are indicated in Table 1. Confirmation of MYXV $\Delta$ serp2 in ddPCR positive tissues was performed using conventional PCR using 100ng of DNA in OneTaq ${ }^{\circledR}$ 2X Master Mix (New England Biolabs, Ipswich, MA, USA). Amplicons were annealed at $52^{\circ} \mathrm{C}$, elongated at $68^{\circ} \mathrm{C}$, and the product was visualized on a $2 \%$ agarose gel. For histopathology, tissues were placed into cassettes and stored in $10 \%$ buffered formalin for at least 1 week. Tissues were then paraffinembedded, sectioned, and stained with hematoxylin and eosin (H\&E) by the Histopathology Section of the Veterinary Diagnostic Laboratory at Colorado State University. Tissue sections were evaluated by a veterinary pathologist (ALM) using light microscopy.

\section{Analysis of the Immune Response}

The immune response to treatment was assessed using histopathology, multiplex serum cytokine analysis, and

Table I Primer Sequences and Specific PCR Parameters Used to Detect MYXV $\Delta$ serp2 DNA in Tissues

\begin{tabular}{|c|c|c|c|c|}
\hline Target Gene Segment(s) & Forward Primer Sequence & Reverse Primer Sequence & $\begin{array}{l}\text { Annealing } \\
\text { Temperature } \\
\left({ }^{\circ} \mathrm{C}\right)\end{array}$ & $\begin{array}{l}\text { Product } \\
\text { Length (Base } \\
\text { Pairs) }\end{array}$ \\
\hline $\begin{array}{l}\text { MYXV M034L (DNA } \\
\text { polymerase) } \\
\text { Glyceraldehyde 3-phosphate } \\
\text { dehydrogenase (GAPDH) } \\
\text { MYXV M033R and M034L }\end{array}$ & $\begin{array}{l}\text { 5' CGC CAT CCT TTA CCT } \\
\text { AAC GA 3' } \\
\text { 5' CGA CTT CAA CAG CAA } \\
\text { CTC CAA CTC TTC C 3' } \\
\text { 5' CAC CCT CTT TAG TAA } \\
\text { AGT ATA CAC C 3' }\end{array}$ & $\begin{array}{l}\text { 5' ACC CGG TGT TAT TTT } \\
\text { TGT CG 3' } \\
\text { 5' TGG GTG GTC CAG GGT } \\
\text { TTC TTC CTC CTT 3' } \\
\text { 5' GAA ATG TTG TCG GAC } \\
\text { GGG 3' }\end{array}$ & $\begin{array}{l}60 \\
60 \\
52\end{array}$ & $\begin{array}{l}87 \\
285 \\
800\end{array}$ \\
\hline
\end{tabular}

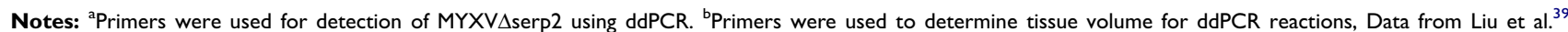
cInterference within tissue type in ddPCR in was observed, therefore primers against MYXV M033R and M034L were used to perform confirmation of ddPCR positive MYXV $\Delta$ serp2 tissues using conventional PCR.

Abbreviations: PCR, polymerase chain reaction; $M Y X V \Delta$ serp2, myxoma virus deleted for serp2; ${ }^{\circ} \mathrm{C}$, degrees Celsius.

Table 2 Tumor Histology Grading Schemes

\begin{tabular}{|l|l|l|l|l|l|}
\hline & Grade 0 & Grade I & Grade 2 & Grade 3 & Grade 4 \\
\hline Percent necrosis & 0 & $\mathrm{I}-15$ & $16-30$ & $3 \mathrm{I}-45$ & $>\mathbf{4 5}$ \\
Percent hemorrhage & 0 & $\mathrm{I}-15$ & $16-30$ & $3 \mathrm{I}-45$ & $>\mathbf{4 5}$ \\
Neutrophils per 400x field* & 0 & $\mathrm{I}-5$ & $5-10$ & $10-20$ & $>20$ \\
Histiocytes per 400x field & 0 & $\mathrm{I}-15$ & $16-30$ & $3 \mathrm{I}-45$ & $>45$ \\
Lymphocytes per 400x field & 0 & $\mathrm{I}-15$ & $16-30$ & $3 \mathrm{I}-45$ & $>\mathbf{4 5}$ \\
\hline
\end{tabular}

Notes: *The grade was increased by I when microabscesses were observed. 
flow cytometry of cells from the spleen. Tumor histopathology sections were processed as previously described. $^{6}$ Briefly, percent necrosis and hemorrhage were estimated. The numbers of inflammatory cells and mitotic figures were counted in ten $400 \times$ microscopic fields and averaged. The grading scheme indicated in Table 2 was followed. Serum cytokine analysis and flow cytometric assays to determine systemic inflammatory responses and activation of lymphoid populations also followed protocols previously described. ${ }^{37}$ Briefly, a multiplex bead array was used to detect the concentrations of 25 cytokines in mouse serum as directed by the manufacturer (BioRad, 23-plex Bio-Plex Pro ${ }^{\mathrm{TM}}$, Hercules, CA, USA; Invitrogen, ProcartaPlex mouse IFNalpha/ IFNbeta Assay, Vienna, Austria). For flow cytometry, nucleated cells were isolated from spleens and lymph nodes, incubated with fluorescent dye-conjugated antibodies (CD3, CD11c, CD14, CD20, CD25, MHCII, and/or NK1.1) that targeted lymphocyte surface markers (BD Biosciences, San Jose, CA, USA), and detected using a CyAn ADP flow cytometer (Beckman Coulter, Brea, CA, USA).

\section{Treatment Efficacy}

The efficacy of treatment was evaluated by observation of clinical signs of disease, calculation of tumor volume and tumor growth rate, determination of median survival time, detection of viral load, and comparison of histopathology. Survival data were recorded from the time of the initial IT injection (Day 0) until euthanasia and plotted using a Kaplan-Meier curve.

\section{Determination of Serum Oclacitinib Concentration}

Sera from mice in each treatment group that were euthanized at Day 4 or Day 7 were pooled so that 6 samples were analyzed: Day 4 PBS, Day 7 PBS, Day 4 MYXVAserp2, Day 7 MYXV $\Delta$ serp2, Day $4 \mathrm{O}+\mathrm{MYXV} \Delta$ serp2, and Day 7 $\mathrm{O}+\mathrm{MYXV} \Delta \mathrm{serp} 2$. The serum concentration of oclacitinib maleate salt was measured using high performance liquid chromatography.

A

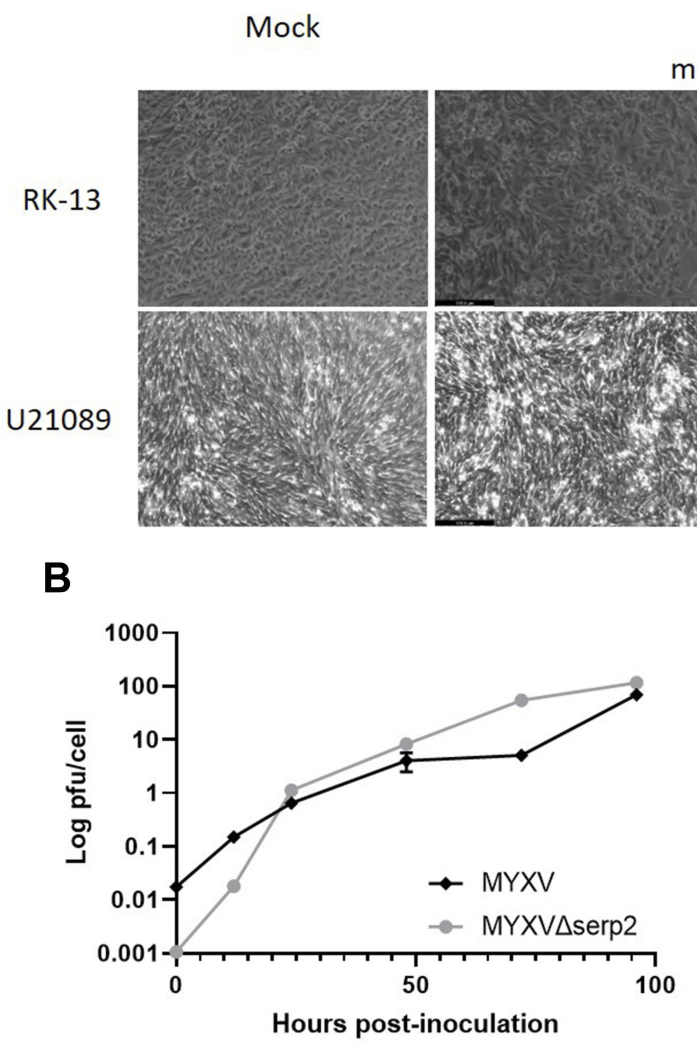

moi $=0.1$

Recombinant MYXV

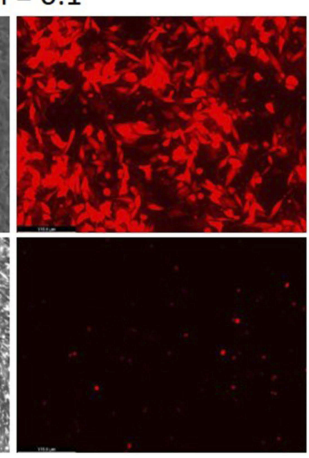

C

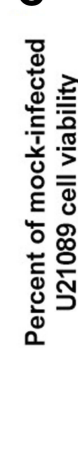

moi $=1$
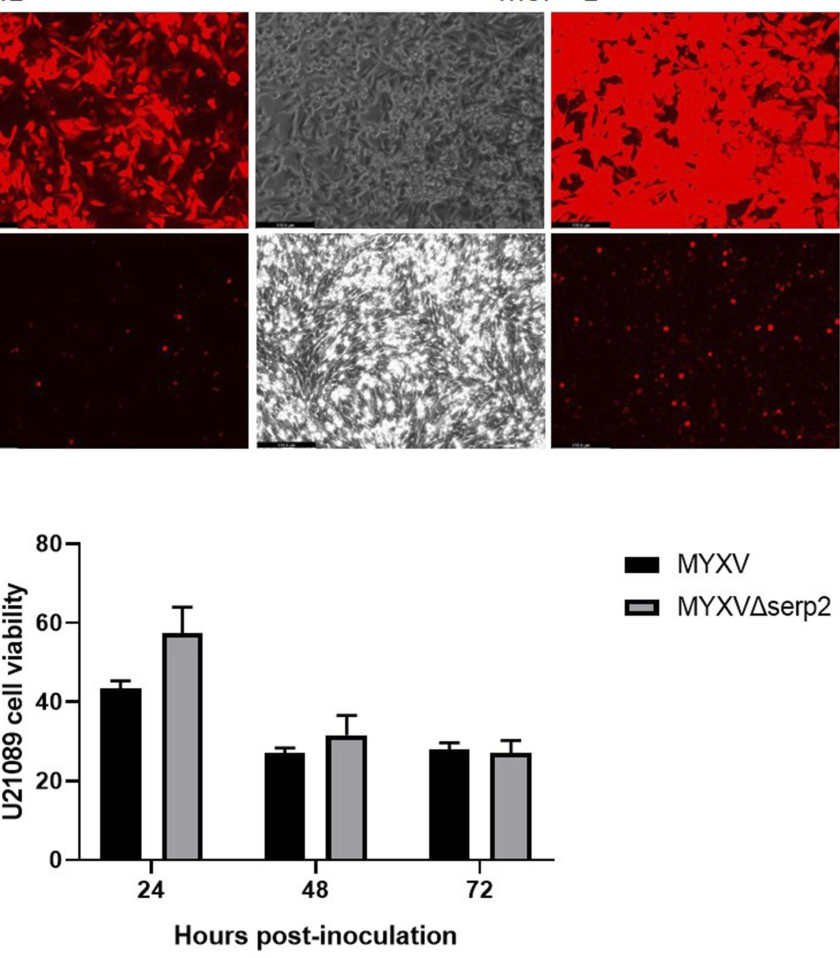

Figure 2 (A) Photomicrographs showing cytopathic effects (phase) and recombinant protein expression (fluorescence) $48 \mathrm{~h}$ post-inoculation (hpi) of RK-13 cells and U2 1089 cells with recombinant MYXV expressing tomato red fluorescent protein [multiplicity of infection (moi) $=0.1$ and I virus particle/cell]. (B) Multi-step viral growth curves. U21089 cells were inoculated with MYXV or MYXV $\Delta$ serp2 (moi $=0.01$ ). Samples were collected at 0, 12, 24, 48, 72, and 96 hpi then plaqued onto RK-13 cells. The number of viral plaque-forming units (pfu) per U21089 cell was calculated from the number of foci that formed in RK-13 cell monolayers. (C) Viability of U2I089 cells after inoculation with myxoma virus $(M Y X V)$ or MYXV $\Delta$ serp2 $(\mathrm{moi}=\mathrm{I})$ expressed as a percentage of viable mock infected U2 1089 cells. Error bars indicate standard error of the mean. 


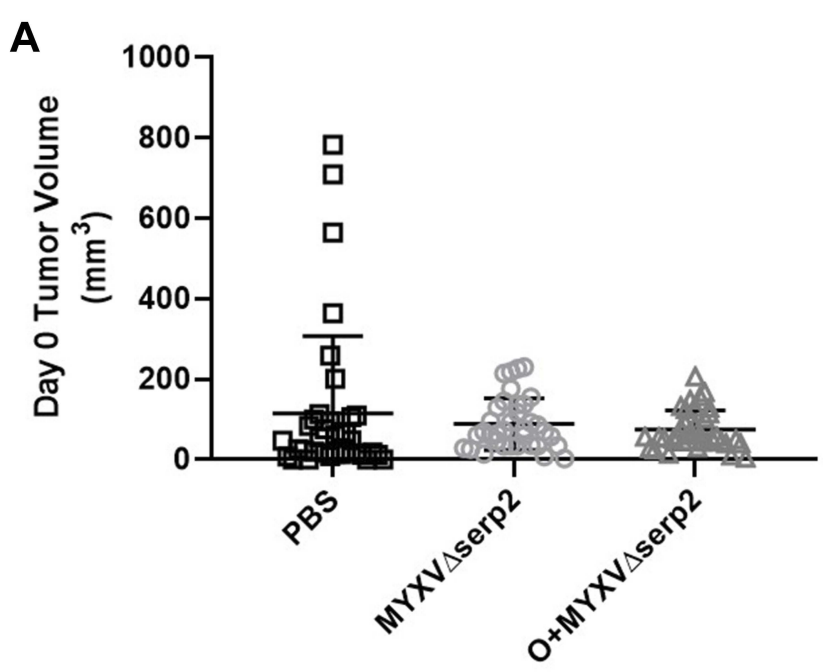

B

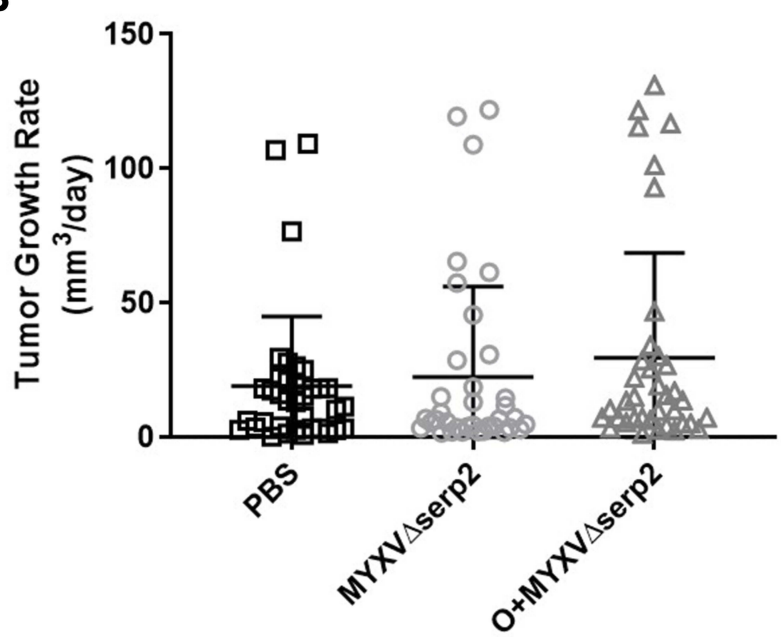

Figure 3 Tumor growth. (A) Tumor volume on the day of the first intratumoral injection (Day 0) and (B) average tumor growth rate calculated from U21089 cell injection until euthanasia in mice treated with phosphate buffered saline (PBS), $M Y X V \Delta$ serp2, and oclacitinib with MYXV $\Delta$ serp2 (O+MYXV $\Delta$ serp2). Error bars indicate mean and standard deviation.

\section{Statistics}

Cell viability percentages, viral titers, serum oclacitinib concentration, histological grades, flow cytometry results, tumor volumes, and tumor growth rates were compared by t-tests using GraphPad Prism software version 8.1.0. The occurrence of clinical signs in mice at Day 0,4 , and 7 were compared with a Chi-square and Fisher's exact test using GraphPad Prism software version 8.1.0. Median survival times were compared with a Cox proportional hazards model using GraphPad Prism software version 8.1.0. Serum cytokine data were analyzed by a statistician $(\mathrm{BG})$ using Dunn's test for comparisons on rank between groups. Associations of sex to cytokine levels were tested separately for each treatment using
Welsh's t-tests. Outlier tests were conducted using the car package version 3.0.2. Analyses were calculated using $\mathrm{R}$ open software version 3.6.0. This program with the fisheries stock analysis package version 0.8 .23 was used for Dunn's test analyses.

\section{Results}

\section{MYXV Replicated in and Induced Lysis of U21089 Cells}

Microscopic cytopathic effects and recombinant protein expression in murine U21089 rhabdomyosarcoma cell cultures suggested that the cells are semi-permissive for MYXV infection (Figure 2A). Logarithmic growth of virus was detected in U21089 cells, confirming that MYXV replication occurs in U21089 cells (Figure 2B). The rates of MYXV and MYXV $\Delta$ serp2 growth in U21089 cells were not significantly different. No significant difference in cell viability was observed when MYXV and MYXV $\Delta$ serp2 infection were compared at any time-point (P-values $\geq 0.181$, Figure 2C). Importantly, MYXV and MYXV $\Delta$ serp2 infection significantly decreased cell viability when compared to mock-infected cells (Figure 2C) at 24 (P-values $\leq 0.023), 48$ (P-values $\leq 0.005)$, and 72 (P-values $\leq 0.002)$ hpi.

\section{U2 1089 Cells Formed Rapidly Growing ARMS Tumors in Nude Mice}

Murine ARMS allografts were established in six- to eleven-week-old, B6.Cg-Foxn1nu/J (nude) mice by injecting $3 \times 10^{6}$ U21089 ARMS cells SQ in the lateral aspect of the thigh. Tumors formed in 100\% (109/109) of the nude mice. The timeline for engraftment and treatments are shown in Figure 1. Some individual variation in tumor size at time of the first IT injection PBS or MYXV $\Delta$ serp2 (designated Day 0) was observed, however the average tumor volumes of the three treatment groups (PBS, MYXV $\Delta$ serp2, and O+MYXV $\Delta$ serp2) were not significantly different (Figure 3A; P-values $>0.22$ ). The rate of tumor growth from the time of U21089 cell injection until euthanasia was similar for mice in all treatment groups (Figure 3B; P-values $>0.17$ ).

\section{Clinical Findings in Mice with ARMS Were Less Severe in Mice Treated with OV}

The gross appearance of tumors on Day 2 varied slightly between individual mice (Figure 4A-C). Ecchymoses at the base of the tumors (Figure 4D), on thighs (Figure 4E), or on 

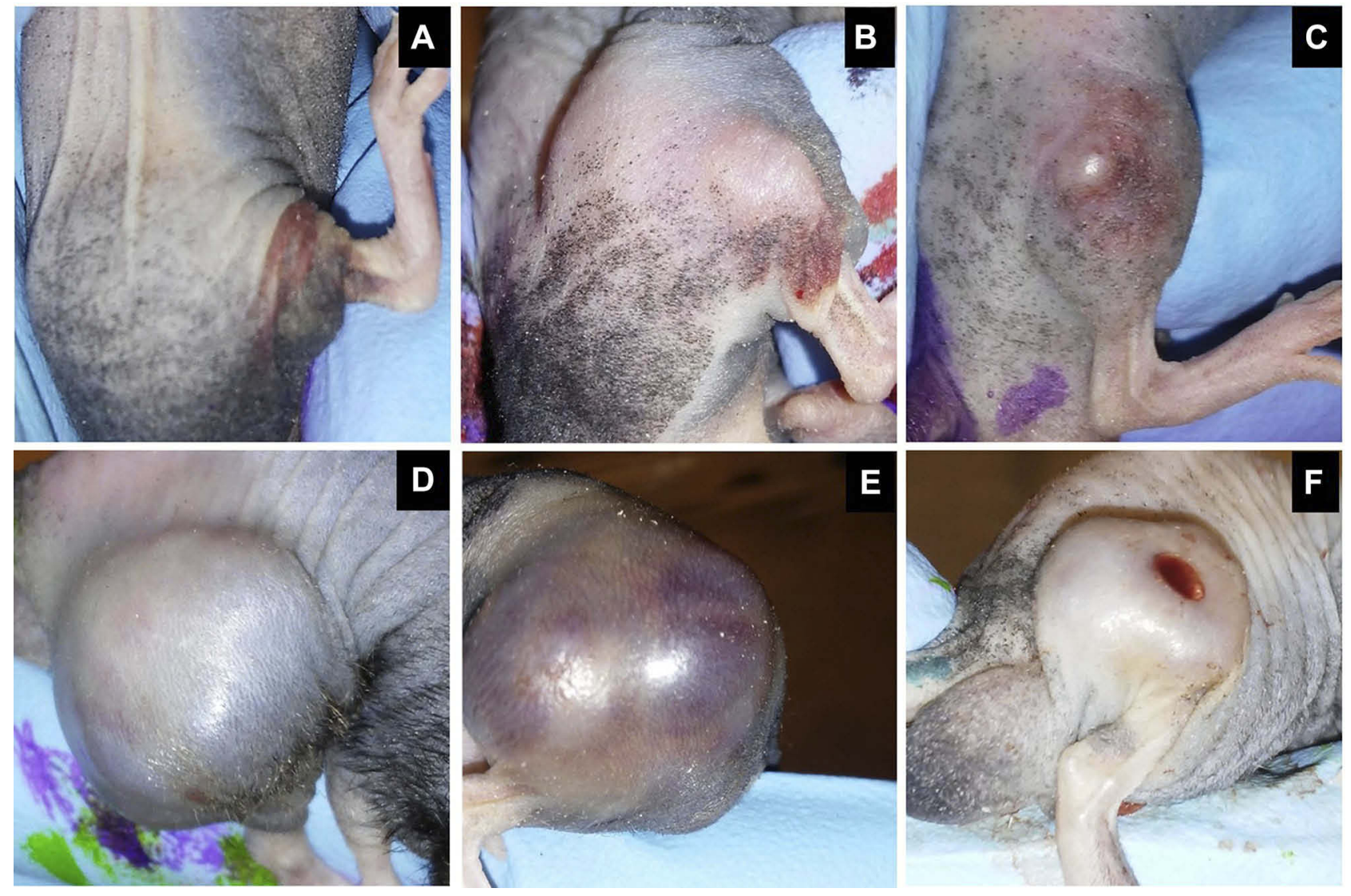

Figure 4 Representative images of subcutaneous rhabdomyosarcoma (RMS) tumors on Day 2 (A-C) and Day 19 (D-F) after the first intratumoral MYXV $\Delta$ serp2 injection. Clinical signs associated with the tumors included erythema (A, B, D), swelling (B, E), ecchymosis (C, D, E), significant tumor development (D, E), and ulceration (F).

abdomens occurred in all mice that met a criterion for euthanasia. Hematomas formed within tumors in 59\% (64/109) of the mice. Hematomas ruptured forming ulcers (Figure 4F) that necessitated euthanasia of $32 \%(12 / 37)$ of the mice that were euthanized after Day 7. The ratio of mice showing clinical signs at Day 0 was significantly higher in the $\mathrm{O}$ + MYXV $\Delta$ serp2 group (Figure 5A; P-value $=0.02$ ), but no significance was noted between treatment groups by Day 4 (Figure 5B; P-value $=0.72$ ). Table 3 summarizes the reasons that mice with ARMS had to be euthanized during this study. In mice evaluated beyond Day 7, 41\% (15/37) mice were euthanized when their calculated tumor volume was $\geq 3500 \mathrm{~mm}^{3}$. Importantly, greater than $50 \%$ of mice in the MYXV $\Delta$ serp2 treated and O+MYXV $\Delta$ serp2 treated groups were surrendered past Day 7 due to the size of the tumor compared to $17 \%(2 / 12)$ of mice in the PBS group. This reflects the finding that clinical signs of disease that necessitated euthanasia (eg lethargy, hunched posture, difficulty moving, weight loss) were less common in mice treated with MYXV $\Delta$ serp2.

\section{Histologic Parameters Revealed Minor Differences Between Treatment Groups}

No histologic abnormalities were observed in organs other than lymph nodes. This supported ddPCR data that indicated O+MYXV $\Delta$ serp2 treatment does not induce unwanted spread of MYXV $\Delta$ serp2 in off-target organs (Table 4). Lymphoid tissue was hyperplastic in low numbers of mice from all treatment groups. Tumors were unencapsulated and were composed of spindle cells arranged in streams and bundles. Cells were separated by a small amount of collagenous matrix. Cells had a small to moderate amount of wispy eosinophilic cytoplasm and a large round to oval nucleus with clumped chromatin and one to four prominent round nucleoli. Marked anisocytosis and anisokaryosis were noted. There were several binucleated cells and 0-3 mitotic figures per $400 \times$ microscopic field. Several tumor sections had areas of necrosis and some were hemorrhagic. Neutrophils were commonly associated with necrotic areas of the tumors and ulceration of the overlying dermis. Small pockets of neutrophils, 

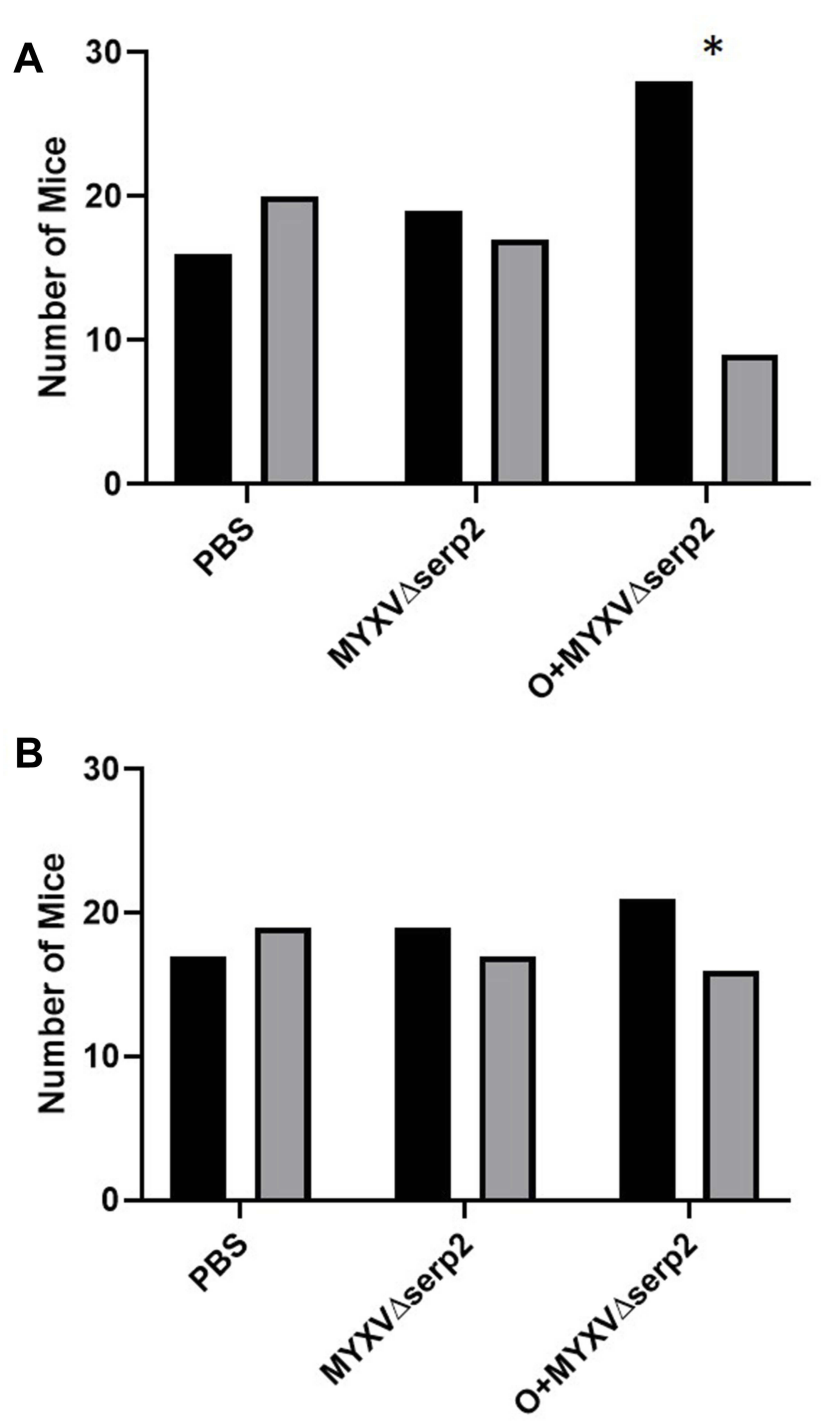

- Clinical Signs $\square$ No Clinical Signs

Figure 5 Contingency graphs indicating the number of mice with and without clinical signs of limb swelling, hematoma formation, erythema, and/or ecchymosis in each treatment group on (A) the day of the first intratumoral injection (Day 0$)$ and (B) Day 4. On Day 0, the ratio of mice treated with oclacitinib with MYXV $\Delta$ serp2 $(\mathrm{O}+\mathrm{MYXV} \Delta$ serp2) that had clinical signs was higher than other treatment groups $($ *P-value $=0.02)$.

consistent with microabscesses, were present within several tumor sections. Histiocytic and lymphocytic inflammation were not observed. Average grades for necrosis (Figure 6A), hemorrhage (Figure 6B), and neutrophilic inflammation (Figure 6C) within tumors were not significantly different between treatment groups in samples collected on Day 4. On Day 7, significantly decreased average hemorrhage and neutrophil grades were observed in $\mathrm{O}+\mathrm{MYXV} \Delta$ serp2-treated mice as compared to MYXV $\Delta$ serp2-treated mice $(\mathrm{P}$-values $=0.05$ and 0.03 , respectively). In mice that met a criterion for euthanasia, animals in the $\mathrm{O}+\mathrm{MYXV} \Delta$ serp2 treatment group had a significantly higher average necrosis grade as compared to mice treated with PBS $(\mathrm{P}$-value $=0.02)$. These differences did not appear to alter tumor volume, tumor growth rate, or median survival time.

\section{Serum Cytokine Concentrations Were Not Affected by Treatment}

Serum cytokine concentrations were determined in all treatments groups of mice on Days 4 and 7, and in mice that met a criterion for euthanasia. No significant differences were observed in any of the following cytokine concentrations: IL- $1 \alpha$, IL- $1 \beta$, IL-2, IL-3, IL-4, IL-5, IL-6, IL-9, IL-10, IL-12 (p40), IL-12 (p70), IL-13, IL-17, eotaxin, GM-CSF, G-CSF, interferon- $\alpha$ (IFN- $\alpha$ ), IFN- $\beta$, IFN- $\gamma$, keratinocyte chemoattractant (CXCL1), monocyte chemoattractant protein-1, macrophage inflammatory protein-1 $\alpha$ (MIP-1 $\alpha$ ), MIP-1 $\beta$, tumor necrosis factor- $\alpha$, or regulated on activation normal $\mathrm{T}$ cell expressed and secreted (CCL5). Graphs of cytokine concentrations can be viewed behind the Colorado State University firewall with this link: https://bgraham-csu.shinyapps.io/bjg mac neill_cytokines/.

\section{Splenocyte Subsets Were Similar in All Treatment Groups}

In mice euthanized on Day 7, cells were isolated from spleens, erythrocytes were lysed, nucleated splenocytes were incubated with antibodies against leukocyte antigens, and cells were analyzed using flow cytometry. Results were gated on intact, singlet cells. When treatment groups were compared, no significant differences were observed in cells consistent with B cells ( $<42 \%$ of splenocytes), natural killer $(\mathrm{NK})$ cells $(<0.74 \%$ of splenocytes $)$, or macrophages $(<1.7 \%$ of splenocytes). As expected, NKT cell and $\mathrm{T}$ cell numbers were extremely low $(<0.030 \%$ of splenocytes).

\section{Median Survival Time in Mice with ARMS} Tumors Was Not Improved by Treatment Mice treated with O+MYXVAserp2 were significantly younger than mice in the other treatment groups (Figure 7A), but this did not cause a significant difference in median survival time (Figure 7B). Likewise, no significant differences in median survival time were observed between male and female mice in any treatment group (Figure 7C). 
Table 3 Reason for Euthanasia of Mice with Rhabdomyosarcoma Allografts

\begin{tabular}{|l|l|l|l|l|}
\hline Treatments & Total Number of Mice & $\begin{array}{l}\text { Tumor Volume } \\
\geq 3500 \mathbf{~ m m}^{3}\end{array}$ & Poor Clinical Condition & Ulceration \\
\hline $\begin{array}{l}\text { Placebo }+ \\
\text { PBS }\end{array}$ & 12 & $2(17 \%)$ & $6(50 \%)$ & $4(33 \%)$ \\
$\begin{array}{l}\text { Placebo }+ \\
\text { MYXV } \Delta \text { serp2 } \\
\text { Oclacitinib }+ \\
\text { MYXV } \Delta \text { serp2 }\end{array}$ & 12 & $6(50 \%)$ & $2(17 \%)$ & $4(33 \%)$ \\
\hline
\end{tabular}

Abbreviations: PBS, phosphate buffered saline. MYXVAserp2, myxoma virus deleted for serp2.

Table 4 Number of Samples in Which MYXVAserp2 DNA Was Detected in Mouse Tissues by Droplet Digital PCR

\begin{tabular}{|c|c|c|c|c|c|c|c|c|c|}
\hline & \multicolumn{3}{|c|}{ Day 4} & \multicolumn{3}{|c|}{ Day 7} & \multicolumn{3}{|c|}{ Survival } \\
\hline & PBS & $\begin{array}{l}\text { MYXV } \\
\Delta \text { serp2 }\end{array}$ & $\begin{array}{l}\text { O+MYXV } \\
\Delta \text { serp2 }\end{array}$ & PBS & $\begin{array}{l}\text { MYXV } \\
\Delta \text { serp2 }\end{array}$ & $\begin{array}{l}\text { O+MYXV } \\
\Delta \text { serp2 }\end{array}$ & PBS & $\begin{array}{l}\text { MYXV } \\
\Delta \text { serp2 }\end{array}$ & $\begin{array}{l}\text { O+MYXV } \\
\Delta \text { serp2 }\end{array}$ \\
\hline Number of mice tested & 12 & 12 & 12 & 12 & 12 & 12 & 12 & 12 & 13 \\
\hline Tumor & 0 & 2 & 6 & 0 & 0 & I & 0 & 0 & $4^{*}$ \\
\hline Brain & 0 & 0 & 0 & 0 & 0 & 0 & 0 & 0 & 0 \\
\hline Gonad & 0 & 0 & 0 & 0 & 0 & 0 & 0 & 0 & 0 \\
\hline Heart & 0 & 0 & 0 & 0 & 0 & 0 & 0 & 0 & 0 \\
\hline Kidney & 0 & 0 & 0 & 0 & 0 & 0 & 0 & 0 & 0 \\
\hline Lung & 0 & 0 & 0 & 0 & 0 & 0 & 0 & 0 & 0 \\
\hline Liver & 0 & 0 & 0 & 0 & 0 & 0 & 0 & 0 & 0 \\
\hline Spleen & 0 & 0 & 0 & 0 & 0 & 0 & 0 & 0 & 0 \\
\hline Salivary gland & 0 & 0 & 0 & 0 & 0 & 0 & 0 & 0 & 0 \\
\hline
\end{tabular}

Note: *Samples were collected I, 6, 7, or 13 days after the second MYXV $\Delta$ serp2 injection.

Abbreviations: MYXV $\Delta$ serp2, myxoma virus deleted for serp2; DNA, deoxyribonucleic acid; PBS, phosphate buffered saline; O, oclacitinib.

\section{MYXV $\Delta$ serp2 Replication Time in ARMS} Tumors Was Extended by Oclacitinib

\section{Treatment}

Oclacitinib maleate salt was detected in the serum of mice treated with oclacitinib on Day 4 (the first day after oral oclacitinib dosing was completed), but not in mice given placebo. By Day 7, serum oclacitinib concentrations were not detectable in any mice. MYXV $\Delta$ serp2 was detected by ddPCR within the tumors of oclacitinib-treated mice up to 13 days after virus inoculation but was not detected beyond Day 4 in mice treated with MYXV $\Delta$ serp2 alone (Table 4).

\section{Discussion}

MYXV $\Delta$ serp2 replication was prolonged in ARMS tumors when combined with oclacitinib treatment as compared to MYXV $\Delta$ serp2 treatment alone. Increasing the length of time that a recombinant MYXV replicated within a tumor microenvironment was a primary goal of this study. Increased MYXV $\Delta$ serp2 replication time in tumors of O+MYXV $\Delta$ serp2-treated mice may be due to inhibition of IFN signaling in the tumor microenvironment by oclacitinib. Oclacitinib inhibits JAK1 and JAK2 activation. ${ }^{31}$ Inhibition of JAK1 activation is expected to prevent IFN signaling in response to virus replication. ${ }^{38}$ Although many tumor cells do not mount and effective type I IFN response to MYXV infection in cell culture, ${ }^{11,28}$ healthy cells in the tumor microenvironment may release IFNs that signal tumor cells to upregulate production of antiviral IFN stimulated genes. Serum concentrations of IFNs and other cytokines were not significantly altered in mice treated with oclacitinib. However, most of the mice in this study had very low concentrations of serum cytokines which may have prevented detection of small changes in $\mathrm{O}$ + MYXV $\Delta$ serp2-treated mice. It is likely that systemic effects of oclacitinib are less important that effects localized to the tumor microenvironment. Unfortunately, due to the lack of treatment efficacy, detection of IFN concentrations within the tumor microenvironment was not pursued. 


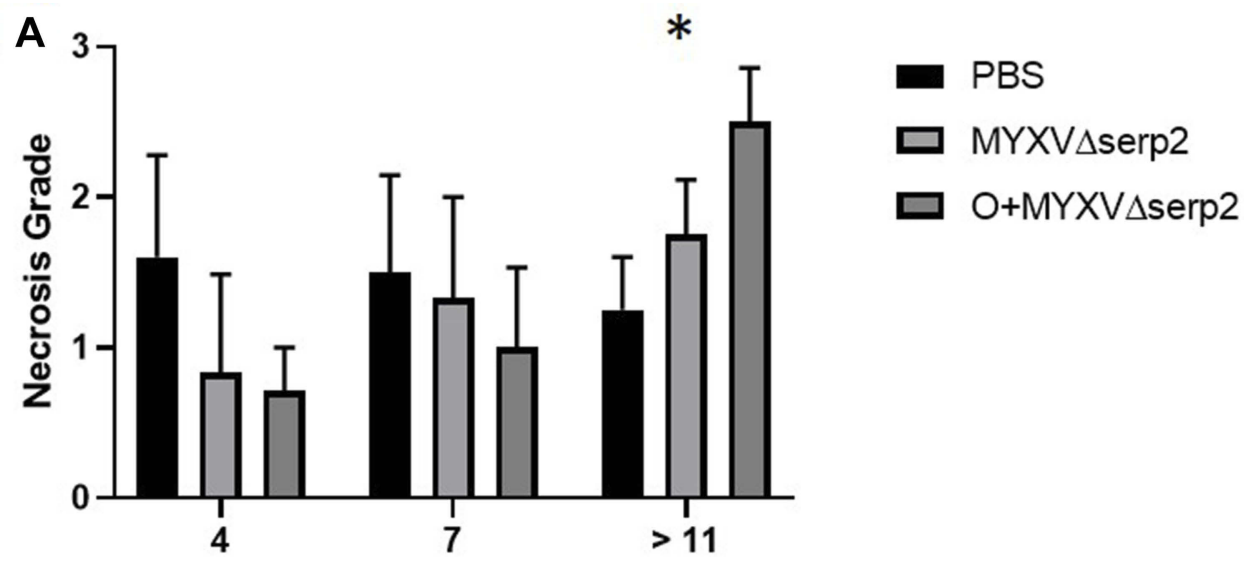

Days After First Injection

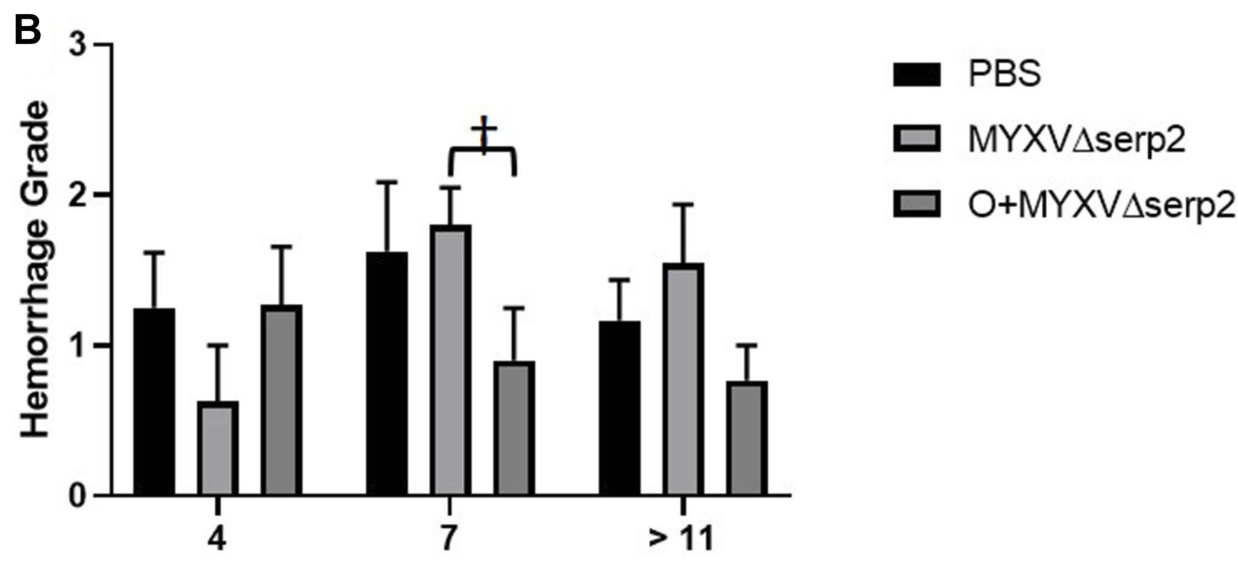

Days After First Injection

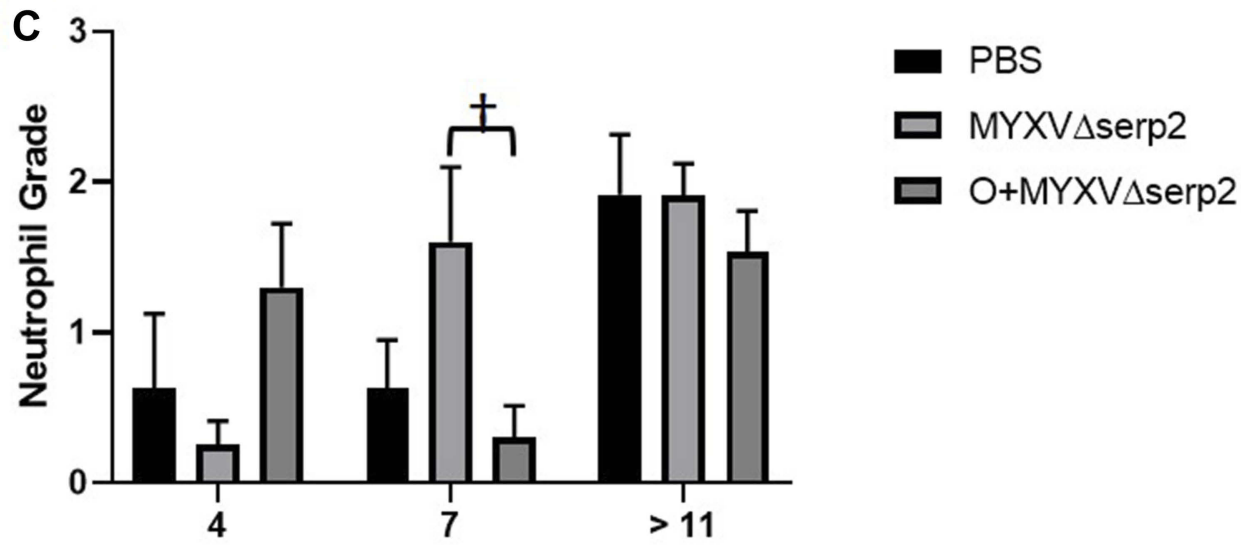

Days After First Injection

Figure 6 Average histologic grades. (A) Necrosis, (B) hemorrhage, and (C) neutrophil grades were determined in histologic sections of tumors collected at the time of euthanasia. Error bars indicate standard error of the mean. *P-value of the $t$-test comparing phosphate buffered saline (PBS) to oclacitinib with MYXV $\Delta$ serp2 (O $+M Y X V \Delta$ serp2) treatment $=0.02$. $\nmid P$-values of the t-tests comparing MYXV $\Delta$ serp2 to $O+M Y X V \Delta$ serp2 treatment $\leq 0.05$

We hypothesized that the longer MYXVAserp2 was able to replicate in tumors, the more effective treatment would be. This was based upon previously published data that showed MYXV replicated for $<7$ days in subcutaneous murine $\mathrm{B} 16 \mathrm{~F} 10$ melanoma allografts ${ }^{23}$ and that frequent injection of MYXV greatly improved outcomes 


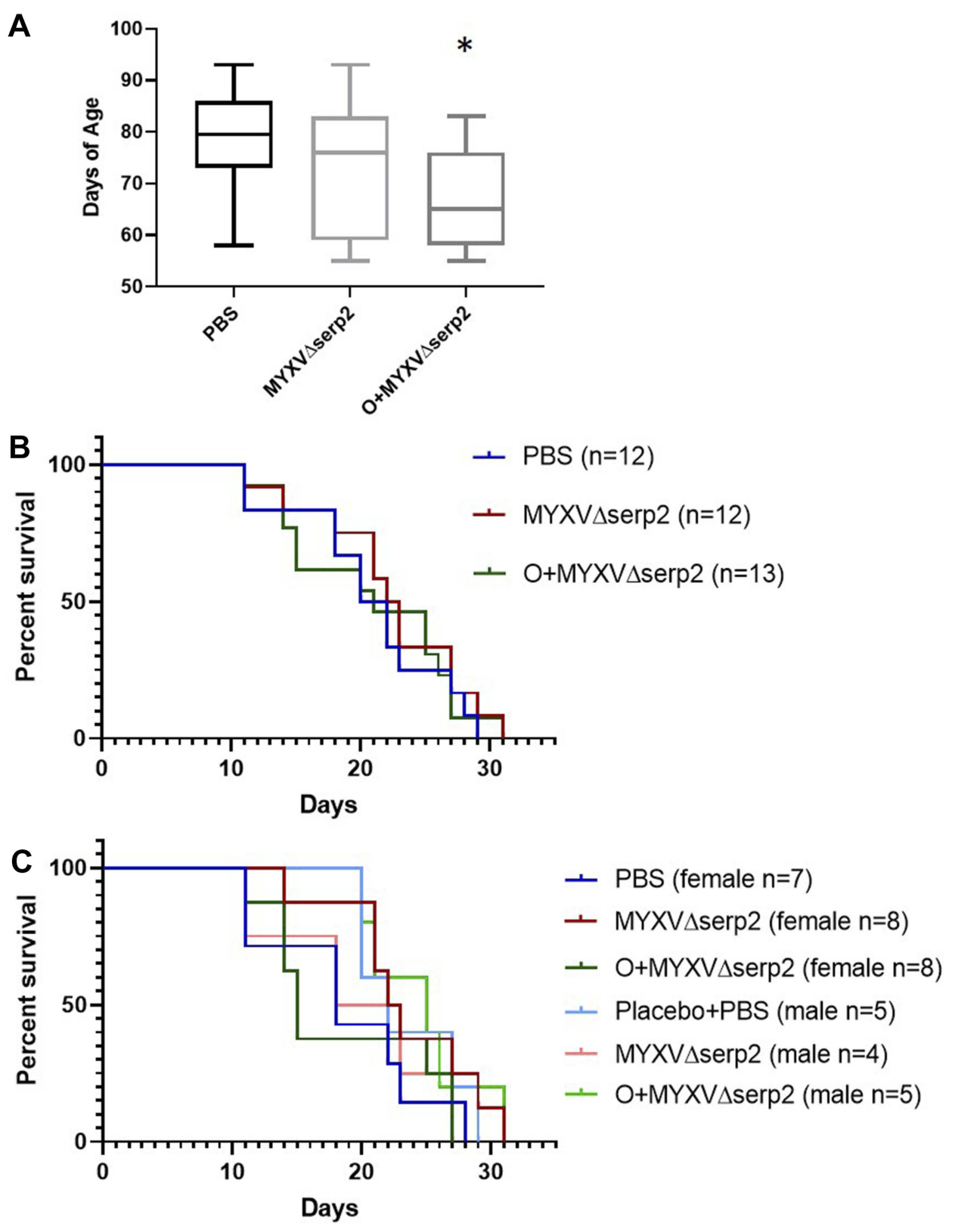

Figure 7 Graphs of $(\mathbf{A})$ age on the day of $U 21089$ cell injection and (B and $\mathbf{C})$ survival outcomes. (A) Mice treated with oclacitinib with MYXV $\Delta$ serp2 (O+MYXV $\Delta$ serp2) were significantly younger than mice in other treatment groups (*P-value $<0.02)$. However, there were no significant differences between $(\mathbf{B})$ median survival times in treatment groups. (C) Likewise, no differences were calculated when median survival times of male and female mice in each treatment group were analyzed independently.

in mice with subcutaneous CCL-136 embryonic RMS xenografts. $^{6}$ This study indicates that prolonged virus replication is not sufficient to improve outcomes in a U21089 ARMS allograft model. Although MYXV $\Delta$ serp2 DNA was isolated from tumors for up to 13 days after virus injection in mice treated with $\mathrm{O}$ $+\mathrm{MYXV} \Delta$ serp2, combination treatment did not decrease the tumor growth rate or median survival time of the mice.

The ARMS allografts that formed following subcutaneous injection of U21089 cells were quickly growing tumors that often became necrotic and hemorrhagic early in the course of disease. Tumors such as these are very challenging to treat with IT injections due to the inability to target viable tumor tissue around the areas of necrosis and hemorrhage. It is possible that other models of cancer would be more amendable to combination oclacitinib and OV therapy. We are currently treating dogs that have spontaneously arising soft tissue sarcomas with combination oclacitinib and MYXV $\Delta$ serp2 therapy. Dogs that have residual disease following tumor excision 
are being enrolled in this study. We hypothesize that dogs who mount an adaptive immune response against MYXV $\Delta$ serp2, will have a prolonged disease-free interval as compared to dogs that do not receive OV therapy.

The most significant finding in this study was the decreased severity of clinical signs in mice treated with MYXV $\Delta$ serp2. Only 2 of 12 mice treated with MYXV $\Delta$ serp2 and 2 of 13 mice treated with combination MYXV $\Delta$ serp2 and oclacitinib had to be euthanized due to poor clinical condition (eg lethargy, hunched posture, difficulty moving, significant loss of weight), whereas 6 of 12 mice treated with placebo reached these criteria for euthanasia. This suggests that OV therapy may help patients with ARMS be more comfortable and experience fewer medical complications during the course of their disease. Additional studies are warranted to evaluate other combination therapies with MYXV $\Delta$ serp2 to improve outcomes for RMS patients.

\section{Conclusion}

Our data indicate that MYXV $\Delta$ serp2 treatment benefits mice with ARMS by reducing clinical signs of disease and improving quality of life.

\section{Acknowledgments}

The Elsa U Pardee Foundation generously funded this study. We thank the undergraduate (Mikaela Maldonado, Garin Wilson) and veterinary (Kayla Gravelle) students who helped with daily evaluation of the mice.

\section{Disclosure}

Ms Barbara Graham reports grants from The Elsa U Pardee Foundation, during the conduct of the study. The authors report no conflicts of interest in this work.

\section{References}

1. Casanova M, Meazza C, Favini F, Fiore M, Morosi C, Ferrari A. Rhabdomyosarcoma of the extremities: a focus on tumors arising in the hand and foot. Pediatr Hematol Oncol. 2009;26(5):321-331. doi:10.1080/08880010902964367

2. Gurria JP, Dasgupta R. Rhabdomyosarcoma and extraosseous ewing sarcoma. Children. 2018;5(12):165. doi:10.3390/children5120165

3. Ognjanovic S, Linabery A, Charbonneau G, Ross J. Trends in childhood RMS incidence and survival in the US. Cancer. 2009;115 (18):4218-4226. doi:10.1002/cncr.24465.Trends

4. Hoang NT, Acevedo LA, Mann MJ, Tolani B. A review of soft-tissue sarcomas: translation of biological advances into treatment measures. Cancer Manag Res. 2018;10:1089-1114. doi:10.2147/CMAR.S1 59641

5. Pol J, Bloy N, Obrist F, et al. Trial watch:: oncolytic viruses for cancer therapy. Oncoimmunology. 2014;3:e28694. doi:10.4161/onci.28694
6. Kinn VG, Hilgenberg VA, MacNeill AL. Myxoma virus therapy for human embryonal rhabdomyosarcoma in a nude mouse model. Oncolytic Virother. 2016;5:59-71. doi:10.2147/OV.S108831

7. Gentschev I, Adelfinger M, Josupeit R, et al. Preclinical evaluation of oncolytic vaccinia virus for therapy of canine soft tissue sarcoma. PLoS One. 2012;7(5):e37239. doi:10.1371/journal.pone.0037239

8. Cinatl J Jr, Cinatl J, Michaelis M, et al. Potent oncolytic activity of multimutated herpes simplex virus G207 in combination with vincristine against human rhabdomyosarcoma. Cancer Res. 2003;63 (7):1508-1514.

9. MacNeill AL, Moldenhauer T, Doty R, Mann T. Myxoma virus induces apoptosis in cultured feline carcinoma cells. Res Vet Sci. 2012;93(2):1036-1038. doi:10.1016/j.rvsc.2011.10.016

10. Urbasic AS, Hynes S, Somrak A, et al. Oncolysis of canine tumor cells by myxoma virus lacking the serp2 gene. Am J Vet Res. 2012;73 (8):1252-1261. doi:10.2460/ajvr.73.8.1252

11. Wang F, Ma Y, Barrett JW, et al. Disruption of Erk-dependent type I interferon induction breaks the myxoma virus species barrier. Nat Immunol. 2004;5(1):1266-1274. doi:10.1038/ni1132

12. Woo Y, Kelly KJ, Stanford MM, et al. Myxoma virus is oncolytic for human pancreatic adenocarcinoma cells. Ann Surg Oncol. 2008;15 (8):2329-2335. doi:10.1245/s10434-008-9924-z

13. Fenner F, Woodroffe GM. The pathogenesis of infectious myxomatosis: the mechanism of infection and the immunological response in the European rabbit (Oryctolagus cuniculus). Br J Exp Pathol. 1953;34(4):400-411.

14. Fenner F. Adventures with poxviruses of vertebrates. FEMS Microbiol Rev. 2000;24:123-133. doi:10.1111/j.1574-6976.2000.tb00536.x

15. Gorski J, Mizak B, Chrobocinska M. Control of rabbit myxomatosis in Poland. Rev Sci Tech. 1994;13(3):869-879. doi:10.20506/rst.13.3.803

16. McCabe VJ, Tarpey I, Spibey N. Vaccination of cats with an attenuated recombinant myxoma virus expressing feline calicivirus capsid protein. Vaccine. 2002;20(19):2454-2462. doi:10.1016/S0264-410X (02)00186-X

17. McCabe VJ, Spibey N. Potential for broad-spectrum protection against feline calicivirus using an attenuated myxoma virus expressing a chimeric FCV capsid protein. Vaccine. 2005;23(46-47):5380-5388. doi:10.1016/j.vaccine.2005.05.038

18. Pignolet B, Boullier S, Gelfi J, et al. Safety and immunogenicity of myxoma virus as a new viral vector for small ruminants. $J$ Gen Virol. 2008;89(Pt 6):1371-1379. doi:10.1099/vir.0.83595-0

19. Thorne SH, Bartlett DL, Kirn DH. The use of oncolytic vaccinia viruses in the treatment of cancer: a new role for an old ally? CurrGene Ther. 2005;5:429-443.

20. Chaudhri G, Panchanathan V, Buller RML, et al. Polarized type 1 cytokine response and cell-mediated immunity determine genetic resistance to mousepox. Proc Natl Acad Sci U S A. 2004;101 (24):9057-9062. doi:10.1073/pnas.0402949101

21. Xu R, Johnson AJ, Liggitt D, Bevan MJ. Cellular and humoral immunity against vaccinia virus infection of mice. $J$ Immunol. 2004;172(1):6265-6271. doi:10.4049/jimmunol.172.10.6265

22. Tosic V, Thomas DL, Kranz DM, et al. Myxoma virus expressing a fusion protein of interleukin-15 (IL15) and IL15 receptor alpha has enhanced antitumor activity. PLoS One. 2014;9(10):e109801. doi:10.1371/journal.pone.0109801

23. Doty RA, McFadden G, Roy EJ, MacNeill AL. Histological evaluation of intratumoral myxoma virus treatment in an immunocompetent mouse model of melanoma. Oncolytic Virother. 2013;2:1-17. doi:10.2147/OV.S37971

24. Lun X, Alain T, Zemp FJ, et al. Myxoma virus virotherapy for glioma in immunocompetent animal models: optimizing administration routes and synergy with rapamycin. Cancer Res. 2010;70 (2):598-608. doi:10.1158/0008-5472.CAN-09-1510

25. Stanford MM, Shaban M, Barrett JW, et al. Myxoma virus oncolysis of primary and metastatic B16F10 mouse tumors in vivo. Mol Ther. 2008;16(1):52-59. doi:10.1038/sj.mt.6300348 
26. Thomas DL, Doty R, Tosic V, et al. Myxoma virus combined with rapamycin treatment enhances adoptive $\mathrm{T}$ cell therapy for murine melanoma brain tumors. Cancer Immunol Immunother. 2011;60 (10):1461-1472. doi:10.1007/s00262-011-1045-Z

27. Lun X, Yang W, Alain T, et al. Myxoma virus is a novel oncolytic virus with significant antitumor activity against experimental human gliomas. Cancer Res. 2005;65(2):9982-9990. doi:10.1158/00085472.CAN-05-1201

28. Bartee E, McFadden G. Human cancer cells have specifically lost the ability to induce the synergistic state caused by tumor necrosis factor plus interferon-beta. Cytokine. 2009;47(3):199-205. doi:10.1016/j. cyto.2009.06.006

29. MacNeill AL, Turner PC, Moyer RW. Mutation of the Myxoma virus SERP2 P1-site to prevent proteinase inhibition causes apoptosis in cultured RK-13 cells and attenuates disease in rabbits, but mutation to alter specificity causes apoptosis without reducing virulence. Virology. 2006;356(1-2):12-22. doi:10.1016/j.virol.2006.07.049

30. Zoetis. APQ1213211 (C) 2014 Zoetis Inc. All rights reserved. Available from: https://www.zoetisus.com/products/dogs/apoquel/ pdf/apoqueltechnicalmonograph.pdf. Accessed May 12, 2020.

31. Gonzales AJ, Bowman JW, Fici GJ, Zhang M, Mann DW, MittonFry M. Oclacitinib (APOQUEL ${ }^{\circledR}$ ) is a novel Janus kinase inhibitor with activity against cytokines involved in allergy. $J$ Vet Pharmacol Ther. 2014;37(4):317-324. doi:10.1111/jvp.12101

32. Taniguchi E, Nichijo K, McCleish A, et al. PDGFR-A is a therapeutic target in alveolar rhabdomyosarcoma. Oncogene. 2008;27(51):51. doi: 10.1038 /onc. 2008.255

33. Liu J, Wennier S, Reinhard M, Roy E, MacNeill A, McFadden G. Myxoma virus expressing interleukin-15 fails to cause lethal myxomatosis in European rabbits. J Virol. 2009;83(11):5933-5938. doi:10.1128/JVI.00204-09
34. Nathaniel R, MacNeill AL, Wang YX, Turner PC, Moyer RW. Cowpox virus CrmA, Myxoma virus SERP2 and baculovirus P35 are not functionally interchangeable caspase inhibitors in poxvirus infections. J Gen Virol. 2004;85:1267-1278. doi:10.1099/vir.0.79 905-0

35. Fukuyama T, Ganchingco JR, Bäumer W. Demonstration of rebound phenomenon following abrupt withdrawal of the JAK1 inhibitor oclacitinib. Eur J Pharmacol. 2017;794(November2016):20-26. doi:10.1016/j.ejphar.2016.11.020

36. Fukuyama T, Ehling S, Cook E, Bäumer W, Baumer W. Topically administered janus-kinase inhibitors tofacitinib and oclacitinib display impressive antipruritic and anti-inflammatory responses in a model of allergic dermatitis. J Pharmacol Exp Ther. 2015;354 (3):394-405. doi:10.1124/jpet.115.223784

37. MacNeill AL, Moldawer LL, Moyer RW. The role of the cowpox virus crmA gene during intratracheal and intradermal infection of C57BL/6 mice. Virology. 2009;384(1):151-160. doi:10.1016/j. virol.2008.10.041

38. O'Shea JJ. Targeting the Jak/STAT pathway for immunosuppression. Ann Rheum Dis. 2004;63(SUPPL. 2):67-71. doi:10.1136/ard.20 04.028290

39. Liu G, Friggeri A, Yang Y, Park YJ, Tsuruta Y, Abraham E. miR-147, a microRNA that is induced upon toll-like receptor stimulation, regulates murine macrophage inflammatory responses. Proc Natl Acad Sci U S A. 2009;106(37):15819-15824. doi:10.1073/pnas.0 901216106
Oncolytic Virotherapy

\section{Publish your work in this journal}

Oncolytic Virotherapy is an international, peer-reviewed, open access online journal publishing original research, study protocols, reviews, editorials and commentaries on all aspects of oncolytic virology, namely the application of oncolytic viruses for the treatment of cancer. Specific topics in the journal include: Rationale and theoretical aspects of oncolytic virotherapy including in vitro, in vivo and mathematical

Submit your manuscript here: http://www.dovepress.com/oncolytic-virotherapy-journal modeling; and practical application and problem solving in the clinic including identification of potential responders through biomarkers and genetic profiling. The manuscript management system is completely online and includes a very quick and fair peer-review system, which is all easy to use. Visit http://www.dovepress.com/ testimonials.php to read real quotes from published authors. 